\title{
Excess Non-COVID-19 Mortality in Portugal: Seven Months after the First Death
}

\author{
André Vieira $^{a}$ Vasco Ricoca Peixoto ${ }^{a}$ Pedro Aguiar ${ }^{a}$ Paulo Sousa $^{a}$ \\ Alexandre Abrantes ${ }^{\mathrm{a}}$ \\ a Public Health Research Center, NOVA National School of Public Health, Universidade NOVA de Lisboa, \\ Lisbon, Portugal
}

\section{Keywords}

Excess mortality $\cdot$ COVID-19 $\cdot$ Epidemiology $\cdot$ Public health surveillance $\cdot$ Portugal

\begin{abstract}
Background: On March 16, 2020, the first death from COVID-19 was recorded in Portugal. Since then, there has been a reorganization of health services, changing the normal approach for the different cases of public health. Excess deaths recorded without a COVID-19 diagnosis are called excess mortality without COVID-19 (EM non-COVID-19). This study aims to estimate the EM non-COVID in the 7-month period after the first registered Covid-19 death. Methods: The following 2 methods were used to estimate the excess mortality in this period: the daily historical average of reported deaths and an adapted auto regressive integrated moving average (ARIMA) model, considering the previous 5 years of records until October 16. For this model, after March 16, data was replaced with the daily historical average deaths from the previous 5 years, simulating the closest scenario possible as there was no pandemic. Only deaths from natural causes were selected for these estimations. For EM non-COVID-19 estimation, we subtracted the COVID-19 deaths from the
\end{abstract}

overall excess mortality. Results: Between March 16, 2020, and October 16, 2020, there was an excess of 6,330 deaths from natural causes, i.e., nearly $12 \%$ more than expected. Both methods estimated an EM non-COVID-19 of around $66-67 \%$ in this period, with a greater relevance in mid-July and mid-September. Conclusions: Excess mortality was present almost every day during the study period. EM nonCOVID-19 seemed to vary over time, showing some inadequacy of healthcare services in management of other patients free of COVID-19 in Portugal during periods with a greater patient volume. It is necessary to take care and monitor COVID-19 cases but also non-COVID-19 cases.

\section{(c) 2021 The Author(s) Published by S. Karger AG, Basel on behalf of NOVA National School of Public Health}

\section{Excesso de mortalidade não-COVID-19: sete meses após o primeiro óbito}

\section{Palavras Chave}

Excesso de mortalidade não-COVID-19 · COVID-19 •

Epidemiologia · Monitorização em saúde pública ·

Portugal (c) 2021 The Author(s). Published by S. Karger AG, Basel on behalf of NOVA National School of Public Health

This is an Open Access article licensed under the Creative Commons Attribution-NonCommercial-4.0 International License (CC BY-NC) (http://www.karger.com/Services/OpenAccessLicense), applicable to the online version of the article only. Usage and distribution for commercial purposes requires written permission.
Correspondence to:

André Vieira, aam.vieira@ensp.unl.pt 


\section{Resumo}

Introdução: Em 16 de março de 2020 foi registado em Portugal o primeiro óbito por COVID-19. Desde então, houve uma reorganização dos serviços de saúde, resultando numa alteração do funcionamento dos serviços de saúde pública. O excesso de óbitos registados sem $\mathrm{CO}$ VID-19 é denominado de Excesso de Mortalidade não-COVID-19 (EM não-COVID-19). O objetivo deste estudo é estimar a EM não-COVID-19 nos primeiros 7 meses após o primeiro óbito por COVID-19 em Portugal. Métodos: Dois métodos foram utilizados para estimar a Mortalidade Excessiva neste período: A média histórica diária de óbitos notificados e um modelo Autorregressivo Integrado de Média Móvel (ARIMA) adaptado, considerando os 5 anos anteriores de registos até 16 de outubro. Para este modelo, a partir de 16 de março, os dados foram substituídos pela média histórica diária de mortes dos 5 anos anteriores, simulando um cenário mais aproximado possível caso não existisse pandemia. Apenas mortes devido a causas naturais foram selecionadas. Para a estimativa do EM não-COVID-19, subtraímos as mortes por COVID-19 à mortalidade geral em excesso. Resultados: Entre 16 de março de 2020 e 16 de outubro de 2020, houve um excedente de 6330 mortes por causas naturais, cerca de 12\% a mais do que o esperado. Ambos os métodos estimaram um EM não-COVID-19 em torno de 66-67\% neste período, com maior relevância em meados de julho e meados de setembro. Conclusões: $\mathrm{O}$ excesso de mortalidade esteve presente quase todos os dias no período de estudo. O EMnão COVID-19 pareceu ter alguma variação ao longo do tempo, evidenciando que momentos com maior volume se possam dever a alguma inadequação dos serviços de saúde na gestão de outros doentes sem COVID-19 em Portugal. É necessário continuar a cuidar e a monitorar os casos COVID-19, mas também os outros casos não COVID-19.

(c) 2021 The Author(s) Published by S. Karger AG, Basel on behalf of NOVA National School of Public Health

\section{Background}

On March 2, 2020, the first positive COVID-19 case in Portugal was recorded, i.e., 13 days before the first death was observed [1]. Since then, several political strategies and reorganizations in all sectors have been required, from restrictions on the economic sector and people's mobility, to health services prioritizing the treatment of this new disease [2].
Different measures have been applied worldwide to fight the virus, but the record of positive cases and deaths registered for this disease is transversal to all countries. In Europe, the countries with the highest overall case fatality rates until October 16 were Italy (9.53\%), United Kingdom $(6.44 \%)$, and Sweden $(5.77 \%)$, but these rates vary when analyzed by age group $[3,4]$. This cross-country estimation may have a nonnegligible degree of error due to different criteria for testing adopted by each country over time $[5,6]$. Portugal recorded 95,902 cases of COVID-19 and 2,149 deaths from COVID-19 on October 16, stating a case fatality rate of $2.24 \%$ at that point [1].

The excess mortality registered above the expected values without including deaths caused by COVID-19 (EM non-COVID-19) may be attributed to collateral effects of this pandemic [7] but also to other reasons. The term "collateral mortality" was used to define the number of deaths caused by delayed or postponed treatment due to the focus of healthcare services on COVID-19 cases, and it is likely to represent a large portion of the EM-nonCOVID-19 [8]. The main goal of this study is to estimate the EM non-COVID-19 in the 7 months after the first reported COVID-19 death in Portugal.

\section{Materials and Methods}

Mortality data was extracted from the Portuguese Death Certificate Information System (SICO-eVM) [9]. We only extracted the number of deaths from natural causes, as we consider that deaths caused by external causes (such as traffic accidents or violence) should not be included in the analysis of EM non-COVID-19 since COVID-19 deaths are registered as deaths from natural causes only. Data on the number of reported COVID-19 deaths in Portugal was extracted from the Directorate-General of Health (DGS) daily Situation Reports, where all persons who died with COVID-19 were counted, unless another obvious and unequivocal cause of death (like a car accident) was identified [10].

We used the following 2 methods to estimate the expected values of daily mortality: (1) in the historical average method, we calculated the historical average of the number of daily all-cause mortality cases for the last 5 years, between March 16 and October 16, and those values are considered the expected value for 2020 if there had been no pandemic; (2) in the ARIMA method, we modeled a time series including the observed mortality from January 1,2010, to March 15, 2020, and the historical average after that day from March 16, 2020, to October 16, 2020. This cut-off point (March 16) was the date of the first reported COVID-19 death and the close inversion in mortality trend. We compared the observed and modeled expected mortality for the pandemic period and the respective $95 \%$ CI. The models were adjusted with a coefficient of determination of $R^{2}=0.823$ (Ljung-Box test, not statistically significant; autocorrelation function and partial autocorrelation function, not statistically significant in the residues; and estimates of the auto parameters - statistically significant regression and moving aver- 


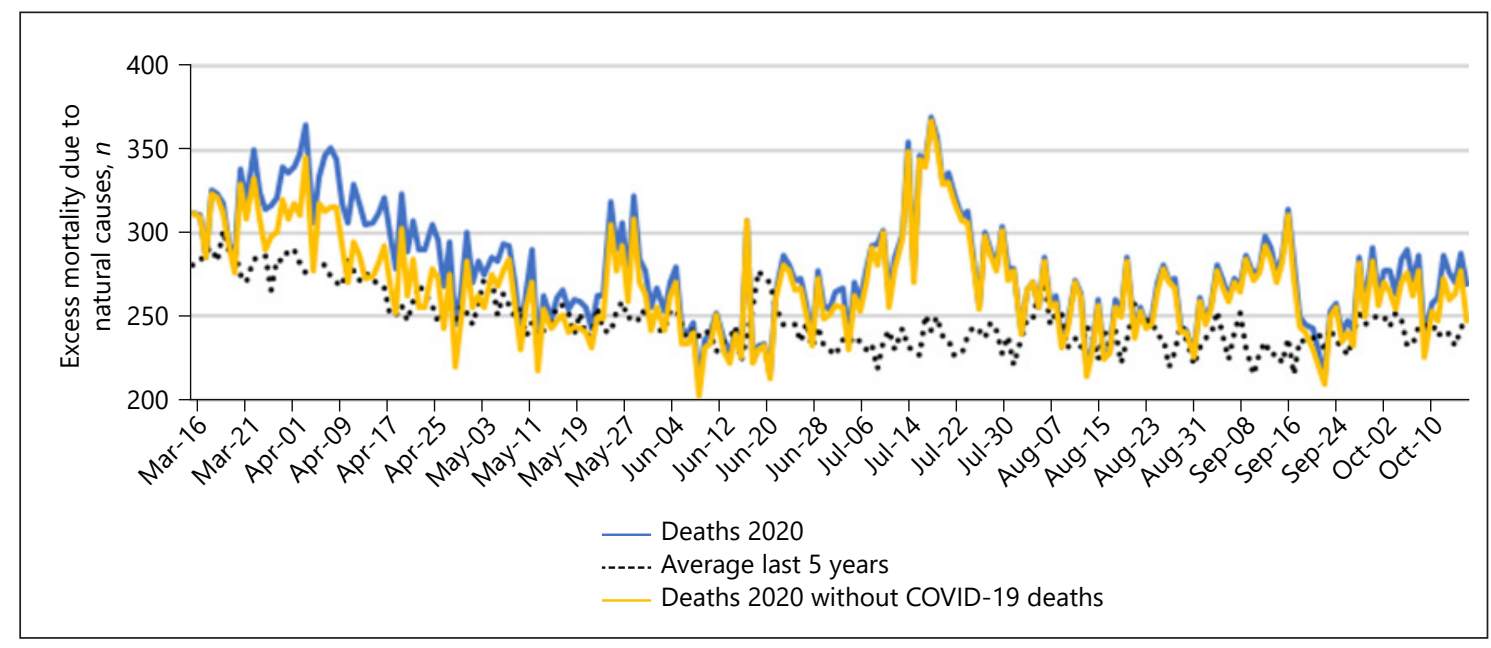

Fig. 1. Excess mortality due to natural causes in 2020 .

ages; $p<0.01$ ) [11]. Tests were performed in $\mathrm{IBM}^{\circledR}$ SPSS software version 24 .

These 2 methods were applied for validation of the results, as performed before in another study [7]. Excess mortality is all the deaths registered above those expected values.

EM non-COVID-19 was calculated by considering the number of non-COVID-19 deaths above the expected values for each method, considering the period of the study. Calculation of the number of excess non-COVID-19 deaths per day was performed by subtracting the total deaths registered free of COVID-19 from the predicted deaths estimated by the ARIMA model, for each day. Then, we calculated the daily proportion of EM non-COVID-19 by dividing the amount of EM non-COVID-19 deaths by all deaths registered beyond the expected values. Days without non-COVID-19 deaths beyond the expected values were valued as $0 \%$.

\section{Results}

\section{Historical Average Method}

For the period in consideration, there were 2,149 deaths with COVID-19. Figure 1 shows the mortality over time.

Table 1 shows the estimated excess mortality for natural causes between March 16 and October 16.

These result presents an EM non-COVID-19 estimation of $67.0 \%$ within the value above the average deaths of the last 5 years (excess mortality non-COVID-19 deaths/ all excess mortality) or $7.3 \%$ of the total observed deaths (excess mortality non-COVID-19 deaths/all deaths).

\section{ARIMA Modeling}

The ARIMA model found similar results, which can be seen in Figure 2.

Excess Non-COVID19 Mortality in Portugal
Table 1. Excess mortality between March 16 and October 16, 2020

\begin{tabular}{lllll}
\hline & $\begin{array}{l}\text { Deaths } \\
\text { in 2020 }\end{array}$ & $\begin{array}{l}\text { Average } \\
\text { in the } \\
\text { last } \\
5 \text { years }\end{array}$ & $\begin{array}{l}\text { Excess } \\
\text { mortality }\end{array}$ & $\begin{array}{l}\text { \% (deaths in } \\
\text { 2020/average } \\
\text { in the last 5 } \\
\text { years) }\end{array}$ \\
\hline All deaths & 59,906 & 53,386 & 6,520 & +12.2 \\
Non-COVID-19 deaths & 57,757 & 4,371 & +8.9 \\
\hline
\end{tabular}

Through the ARIMA method, 53,573 deaths caused by natural causes were predicted in the period between March 16 and October 16. There were 6,330 more deaths than predicted in the forecast if there had been no pandemic. If we remove the deaths registered as COVID-19 (2,149 deaths), we register an EM non-COVID-19 of about 4,181 deaths. This represents $66.1 \%$ of the registered excess mortality or $7.0 \%$ of the total deaths registered by natural causes.

Figure 3 shows an illustration that can help to understand the results.

Also, in Figure 4, we can see the EM non-COVID-19 per day as frequencies and percentages.

Between April and mid-June, COVID-19 deaths contributed, to some degree, to the excess mortality seen in Portugal. However, since early July, excess mortality was present almost every day, with main deaths bellowing to non-direct COVID-19 diagnoses. Although the daily contribution of non-COVID-19 deaths to the daily excess mortality has changed over time, the number of non-CO- 
Fig. 2. Evolution of mortality due to natural causes only, analyzed using the ARIMA model.
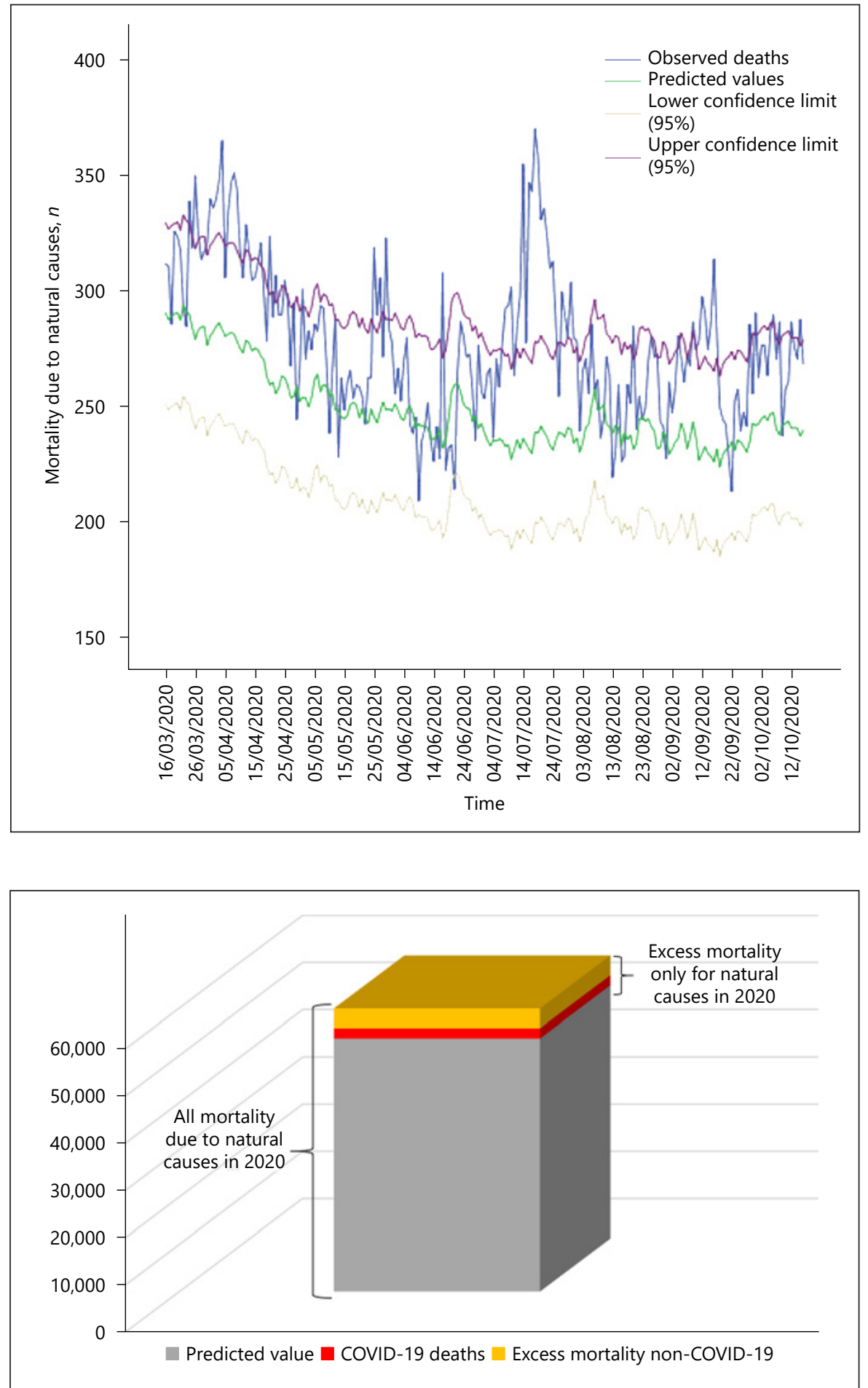

Fig. 3. Schematic representation of the mortality in Portugal between March 16 and October 16, 2020.
VID-19 deaths has largely oscillated and it is therefore not possible to identify a clear trend. The proportions of nonCOVID-19 deaths seemed to increase from mid-April to mid-July but from mid-July to mid-September they seemed to remain stable (and high), decreasing until midOctober. Excess mortality existed and was mainly attributed to non-COVID-19 deaths on those days when the percentages where higher. 
Fig. 4. Daily analysis of collateral deaths.

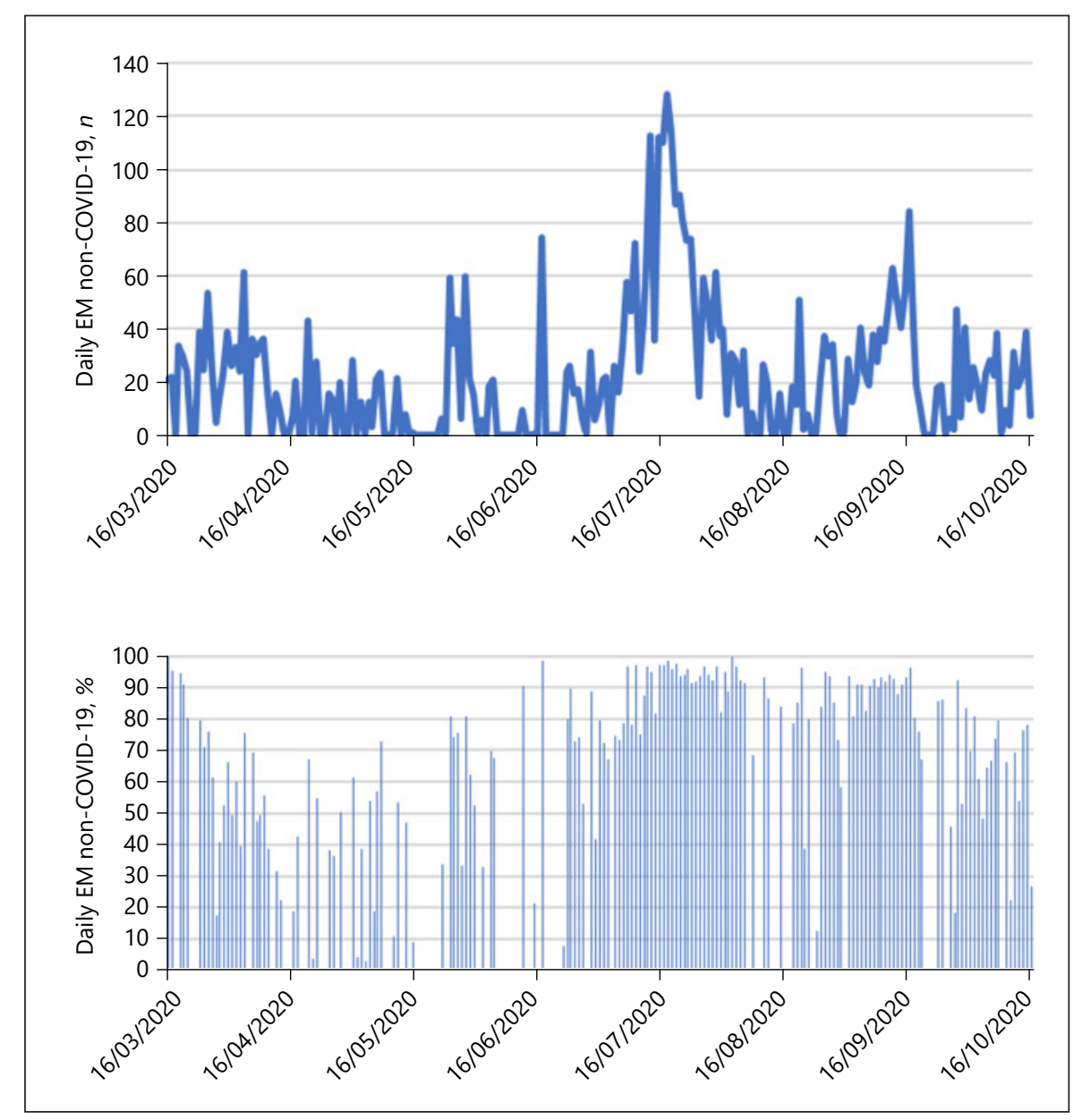

\section{Discussion/Conclusion}

The findings of our analysis suggest an EM non-COVID-19 between 66.1 and 67.0\% for the COVID-19 pandemic in Portugal for the period between March 16 and October 16, 2020. This percentage is related to the excess mortality calculated for natural causes only.

The results are consistent, using 2 different methods for estimation, as performed in an earlier study at the beginning of the pandemic [7]. In that study, we found that nearly 1 month after the first registered COVID-19 death in Portugal the EM non-COVID-19 was around 51\%. Regardless of the lockdown measures and restrictions applied over time, this percentage increased after 6 months, which means that, in general, we still observed a sum of deaths above the expected values and more of them were registered as causes other than COVID-19 [2]. These are important findings, as we expected the arrival of the winter to drastically increase coronavirus [12]. In fact, the pressure on the health system was greater this October 2020 compared to the summer time, potentially due to a greater period of access to hospitals and health services, even without the typical activity of flu expected for this time of the year $[1,13,14]$. The reduction in the incidence of others respiratory infections could have contributed to mitigation of the verified excess mortality.

On October 16, Portugal had an incidence of COVID-19 mortality of 20.91/100.000, being classified as a country with a moderate mortality due to COVID-19 at the time $[1,15]$. One explanation for this excess can be the impact of heat waves. According to the World Meteorological Organization (WCDMP No.47, WMO-TD No. 1071), a heat wave is defined as an interval of at least 6 consecutive days during which the maximum daily temperature is $5^{\circ} \mathrm{C}$ higher than the average daily value in the reference period [16]. Thus, there may have been a heat wave in the periods from May 24 to 29 and from July 15 to 17,2020 , which corresponds to the 2 peaks observed 
for EM non-COVID-19 [17]. Therefore, the hypothesis that people's health deteriorated and they possibly died due to spiking temperatures, while not seeking medical attention due to fear of COVID-19 and medical care not being focused on these episodes, should not be ruled out. However, the increase in EM non-COVID-19 in midSeptember cannot be attributed to temperature variations and thus other causes may be underlying this phenomenon.

Recently, a study of Tanne [18] showed that $33 \%$ of deaths between March and July 2020 throughout the USA were EM non-COVID-19 deaths [18]. Woolf et al. [19] found that these percentages of EM non-COVID-19 deaths could vary from none to nearly $83 \%$, depending on the state. In Europe, estimations require more updates. In a recent article by Kontis et al. [20], it was estimated that in late May 2020 England and Wales, Italy, and Spain had $57,300,48,700$, and 45,800 excess deaths, respectively, while Portugal recorded 2,900. Respectively, the rates of EM non-COVID-19 significantly differed between those countries (i.e., 28.8, 32.5, 61.8, and 51.9\%). These values are relevant tools for policy makers, as they help to understand whether the excess deaths counted are primarily due to the management of COVID-19 cases or the management of other disease cases.

Kontis et al. [20] and Woolf et al. [19] hypothesized that some of the excess deaths could have been due to undiagnosed COVID-19; however, we considered this a very remote supposition in Portugal as, since midMarch, the criteria for postmortem testing for COVID-19 were broad and updated through time [21]. In the UK, it was found that about $7.8 \%$ of deaths with COVID-19 on the death certificate but not stated as the underlying cause were not considered a "COVID-19 death" [22]. However, we think that the death certificate system in Portugal registered most people who died with COVID-19 (even if it was not the underlying cause) in the category of COVID-19 deaths, as since April Portugal adopted the practice of counting deaths with COVID-19 and not only by COVID-19 [23]. So, we believe that the number of deaths with COVID-19 misclassified should not be significant. Other possible contributions to those high numbers of EM non-COVID-19 can be explained by the population being afraid to seek hospital emergency services due to the risk of becoming infected, or the healthcare services' inability to provide the regular quality of service to non-COVID-19 patients after the organizational restructurings $[2,17]$, i.e., the so called earlier collateral mortality. The availability of daily data used by the health services and specific causes of death can contribute to other parallel analyses that could better explain these results.

In the study period, the maximum bed occupation due to patients with COVID-19 in intensive care units was 271, on April 7, out of 511 beds available before the pandemic [10]. That represents more than half of the intensive care unit beds occupied by COVID-19 cases. The pandemic's age distribution is also changing over time, with mostly young people apparently currently being affecting [10]. Although this subpopulation has a greater capacity to survive the disease, an increasing number of overall cases would nonetheless overload the healthcare systems and more cases of deaths among younger people have been described. The underuse of health services, stringency measures, and public behavior regarding measures may play a big role in the mortality soon.

The methodology used in this study has some limitations. First, the use of the average value of the last 5 years without considering any standard of error does not reach the variability of reported deaths through the years for the same day. Also, the expected values of excess deaths may be overestimated, considering the long-term trend of mortality due to demographic, health, and social changes (between 2015 and 2019, the sum of the variation in the mortality growth rate from one year to the next, yielded an overall rate of $1.3 \%$, but 2019 had a value of $-1.1 \%$ related to 2018 so we did not assume that this was relevant for these estimations, considering the short period) [24].

We found our study to be one of the few studies estimating excess mortality from natural causes (instead of overall causes) during the COVID-19 pandemic. Further research is needed to better understand the drivers of excess mortality during the COVID-19 pandemic in different periods of time, considering healthcare supply and demand (including changes in consultations, surgery, and emergency services used by patients) and social, behavioral, and economic changes that may impact mortality through different mechanisms.

\section{Statement of Ethics}

All of the analyses in this study were performed using anonymized data available from public sources. All of the procedures were performed according to the ethical principles of the Declaration of Helsinki.

\section{Conflict of Interest Statement}

The authors declare they have no conflict of interests. DOI: $10.1159 / 000515656$
Vieira/Ricoca Peixoto/Aguiar/Sousa/ Abrantes 


\section{Funding Sources}

No financial support was received.

\section{Author Contributions}

It was ensured that the authorship granted to this study was adequate. Below we represent the roles that each author played according to the CRediT author statement. A.V.: conceptualization, methodology, formal analysis, and writing of the original draft. V.R.P.: methodology, formal analysis, and validation. P.A.: formal analysis and validation. P.S.: writing, review, and editing. A.A.: conceptualization, writing, review, and editing. We ensure that this is an entirely original work, and if we have used the work and/ or words of others this has been appropriately cited or quoted. We assume that this work has not been published elsewhere. We know that, if we discover a significant error or inaccuracy in our published work, it is our obligation to promptly notify the journal editor or publisher and cooperate with the editor to retract or correct the paper. All of the data used were anonymized.

\section{References}

1 European Centre for Disease Prevention and Control. Daily update of new reported cases of COVID-19 by country worldwide. Stockholm: European Centre for Disease Prevention and Control; 2020.

2 Peixoto VR, Vieira A, Aguiar P, Carvalho C, Thomas D, Abrantes A. Rapid assessment of the impact of lockdown on the COVID-19 epidemic in Portugal. medRxiv. 2020; 1-14.

3 Best RD. Coronavirus (COVID-19) death rate in countries with confirmed deaths and over 1,000 reported cases as of October 16, 2020, by country [Internet]. New York: Statista; 2020 [cited 2020 Oct 16]. Available from: https://www.statista.com/statistics/1105914/ coronavirus-death-rates-worldwide/.

4 Dudel C, Riffe T, Acosta E, van Raalte A, Strozza C, Myrskylä M. Monitoring trends and differences in COVID-19 case-fatality rates using decomposition methods: contributions of age structure and age-specific fatality. PLoS One. 2020 Sep;15(9):e0238904.

5 Hasell J, Mathieu E, Beltekian D, Macdonald B, Giattino C, Ortiz-Ospina E, et al. A crosscountry database of COVID-19 testing. Sci Data. 2020 Oct; 7(1):345.

6 Worldometer. Coronavirus testing: criteria and numbers by country 2020 - current testing numbers by country [Internet]. New York: Dadax; 2020 [cited 2020 Oct 16]. Available from: https://www.worldometers.info/ coronavirus/covid-19-testing/.

7 Vieira A, Peixoto VR, Aguiar P, Abrantes A. Rapid estimation of excess mortality during the covid-19 pandemic in Portugal: beyond reported deaths. J Epidemiol Glob Health. 2020 Sep;10(3):209-13.

8 Tan KK, Moran BJ, Solomon MJ. Avoiding collateral mortality in a pandemic - time to change our mindset in surgical oncology. Nat Rev Clin Oncol. 2020 Jul;17(7):383-5.
9 Ministério da Saúde. Sistema de Informação de Certificado de Óbito (SICO): vigilância de mortalidade [Internet]. Lisbon: Ministério da Saúde; 2020 [cited 2020 Apr 15]. Available from: https://evm.min-saude.pt/.

10 Ministério da Saúde. Ponto de situação atual em Portugal. Lisboa: Direção-Geral da Saúde; 2020. Available from: https://covid19.minsaude.pt/ponto-de-situacao-atual-em-portugal/.

11 Fidel LS, Tabachnick BG. Using multivariate statistics. 6th ed. London: Pearson Education; 2012.

12 Merow C, Urban MC. Seasonality and uncertainty in global COVID-19 growth rates. Proc Natl Acad Sci USA. 2020 Nov;117(44):2745664.

13 Ministério da Saúde. Plano de contingência saúde sazonal: módulo inverno. Lisbon: Direção-Geral da Saúde; 2019.

14 Ministério da Saúde. Boletim de vigilância epidemiológica da gripe e outros vírus respiratórios: 2020 Semana 53 - de $28 \mathrm{dez}$ a 03 jan. Lisbon: Instituto Nacional de Saúde Dr. Ricardo Jorge; 2020.

15 Bilinski A, Emanuel EJ. COVID-19 and excess all-cause mortality in the US and 18 comparison countries. JAMA. 2020 Nov;324(20): $2100-2$.

16 World Meteorological Organization. Guidelines on the definition and monitoring of extreme weather and climate events: draft. Geneva: WMO; 2018.

17 Vieira A, Peixoto VR, Aguiar P, Sousa P, Zampaglione G, Abrantes A. Excesso de mortalidade, mortalidade colateral e resposta dos serviços de saúde em Portugal em tempos de COVID-19: relatório de 02-11-2020 [Internet]. Lisbon: Universidade Nova de Lisboa; 2020. [cited 2020 Nov 16]. Available from https://barometro-covid-19.ensp.unl.pt/wp- content/uploads/2020/11/excesso-de-mortalidade-colateral-temperaturas-e-no-deatos-02.11.2020.pdf.

18 Tanne JH. Covid-19: at least two thirds of 225 000 excess deaths in US were due to virus. BMJ. 2020 Oct;371:m3948.

19 Woolf SH, Chapman DA, Sabo RT, Weinberger DM, Hill L, Taylor DD. Excess deaths from COVID-19 and other causes, MarchJuly 2020. JAMA. 2020 Oct;324(15):1562-4.

20 Kontis V, Bennett JE, Rashid T, Parks RM, Pearson-Stuttard J, Guillot M, et al. Magnitude, demographics and dynamics of the effect of the first wave of the COVID-19 pandemic on all-cause mortality in 21 industrialized countries. Nat Med. 2020 Dec;26(12): 1919-28.

21 Ministério da Saúde. Norma 002/2020 de 16/03/2020 e atualizada a 03/07/2020: COVID-19 - procedimentos post mortem. Lisbon: Ministério da Saúde; 2020.

22 Centre for Evidence-Based Medicine. Death certificate data: COVID-19 as the underlying cause of death 2020 [Internet]. Oxford: CEBM; 2020 [cited 2020 Sep 16]. Available from: https://www.cebm.net/covid-19/deathcertificate-data-covid-19-as-the-underlyingcause-of-death/.

23 Kotowicz A. Os países contam as mortes por Covid de forma diferente: contagem em Portugal considera mais casos [Internet]. 2020 [cited 2020 Sep 16]. Available from: https:// observador.pt/especiais/os-paises-contamas-mortes-por-covid-de-forma-diferentecontagem-em-portugal-considera-mais-casos/.

24 Pordata. Taxa bruta de mortalidade 2020 [Internet]. Lisbon: Fundação Francisco Manuel dos Santos; 2020 [cited 2020 Jun 15]. Available from: https://www.pordata.pt/DB/Municipios/Ambiente+de+Consulta/Tabela.
Excess Non-COVID19 Mortality in Portugal
Port J Public Health 2020;38(suppl 1):51-57 DOI: $10.1159 / 000515656$ 